\title{
A problemática do humor na atividade do motorista de ônibus
}

The problems of the humor in the activity of the bus driver

El problema del humor en la actividad del conductor del autobús

\section{Jésio Zamboni}

Universidade Federal do Espírito Santo, Vitória, ES, Brasil

Maria Elizabeth Barros de Barros

Universidade Federal do Espírito Santo, Vitória, ES, Brasil

\section{Resumo}

Esse ensaio clínico discute o trabalho do motorista de ônibus do transporte coletivo urbano pela perspectiva da atividade. Colocam-se em jogo as ferramentas analíticas da clínica da atividade e da esquizoanálise em função dos dispositivos de análise desenvolvidos entre os próprios trabalhadores. Aborda-se a formulação de paradoxos do trabalho como situações problemáticas vívidas entre os motoristas. O paradoxo das perguntas sem resposta e um trecho dialógico entre clínico do trabalho e motorista funcionam como eixos do desenvolvimento analítico. O humor figura como fonte e recurso para a intervenção clínica no trabalho, para além de uma definição individual, como modos de circulação dos afetos entre motoristas e seus outros. Esta análise situada do trabalho ressalta como a atividade do trabalhador não se limita à operação técnica dos aparelhos, mas envolve uma dimensão de subjetividade que permeia as relações entre homens e máquinas.

Palavras-chave: Motoristas; Atividade; Trabalho; Humor.

\begin{abstract}
This clinical essay discusses the work of the bus drivers in the urban mass transit from the perspective of activity. It puts in play the analytical tools of the clinic of activity and of the schizoanalysis. It approaches the formulation of paradoxes of the work as problematic situations livable among the drivers. The paradox of the unanswered questions and a snippet of dialogue between the clinician of work and the bus driver function as axes of analytical development. Humor appears as a source and a resource for clinical intervention at work, beyond an individual definition, as modes of circulation of the affections between the drivers and their others. This situated analysis of the work of the bus driver highlights how the
\end{abstract}


activity of the worker is not limited to the technical operation of the equipment, but involves a dimension of subjectivity that permeates the relations between men and machines.

Keywords: Drivers; Activity; Labour; Humor.

\section{Resumen}

En este ensayo clínico se analiza el trabajo de transporte urbano del conductor de autobús desde la perspectiva de la actividad. Se ponen en juego las herramientas analíticas de la clínica de la actividad y esquizoanálisis según los dispositivos de análisis desarrollados entre los propios trabajadores. Se aborda la formulación de paradojas del trabajo como situaciones problemáticas vívidas entre los conductores. La paradoja de las preguntas sin respuesta y un fragmento de diálogo entre clínico del trabajo y conductor funcionan como ejes de desarrollo analítico. El humor es fuente y recurso para la intervención clínica en el trabajo, además de una definición única, como modos de circulación de afectos entre los conductores y sus otros. Este análisis situado subraya como la actividad del trabajador no se limita a la operación técnica de los equipos, sino que implica una dimensión de la subjetividad que impregna las relaciones entre hombres y máquinas.

Palabras clave: Motoristas; Actividad; Trabajo; Humor.

\section{A construção como essência:}

\section{humorística dos acontecimentos entre motoristas}

O que $e ́$ a atividade do motorista de ônibus coletivo urbano? É crucial que esta questão entre pelo meio da atividade se constituindo. De tal modo que esse ser nunca chegue, que esteja sempre a meio caminho, sempre fazendo caminho. E não é sempre no meio do caminho que o motorista trabalha? Ainda quando chega ao terminal, ali o meio do caminho só se intensifica, se cruza a vários outros meios caminhos. Mesmo o ponto final é só uma curva pra refazer de novo o caminho.
Atualizar o caminho por sua repetição diferencial. Fazer de novo não é fazer o mesmo. Nunca é o mesmo caminho que se faz, nunca é do mesmo modo, nunca a mesma experiência. Ainda que, por vezes, essa experiência do mesmo se apresente. E sempre pela repetição. Então, cabe torcer a pergunta inicial, dispensando o acento à questão do ser, e perguntar: $e$ a atividade do motorista de ônibus?

$\mathrm{O} e$ remete às múltiplas conexões que se fazem pelos meios do caminho e que impedem definir completamente o que possa ser o motorista de ônibus. A essência do trabalho do motorista se constrói na relação com outras forças, sempre diversas 
e diversificando-se - como podemos pensar a partir de "Nietzsche e a filosofia" (Deleuze, 1962/1976). Essa própria essência, essa força característica do motorista, varia e multiplica seus sentidos em função dessas forças diversas. $\mathrm{O}$ movimento de ser, de existir, de construirse, de compor-se, é o que nos interessa no motorista de ônibus; o que implica perseverar em sua própria existência, paradoxalmente, transformando-se. O que é esse trabalho do motorista, ou seja, a essência dessa atividade produtiva está sempre em questão, em jogo, convocado à construção pela situação de trabalho sempre singularizante, cheia de imprevistos, de acontecimentos a acompanhar e a dar passagem. Nosso problema neste ensaio clínico se afirma, então, nessa pergunta: como se produz a atividade do motorista de ônibus? Como se constrói o trabalho do motorista de ônibus?

Se, por um lado, conhecer o trabalho do motorista de ônibus coletivo urbano requer abordar as regras e prescrições até certo ponto visíveis e oficiais; por outro, implica também abordar normas e tarefas um tanto mais invisíveis, molecularizadas em oficialidades menores, para que se possa acompanhar o processo de produção daquelas que se estabelecem - como nos indica a "Ergonomia" (Falzon, 2004/2007). Além disso, saber como se faz o trabalho implica ainda que se trate das estratégias que se inventam - para além das definições em prescrições e tarefas -, ou seja, as experimentações no trabalho, que são a fonte de definições possíveis. Portanto, como se constitui a atividade do motorista de ônibus é um problema sempre inacabado, aberto, incômodo, presente a cada instante, a cada movimento e a cada parada no trabalho. Como nos diz Clot (2006/2011, p. 74),

\footnotetext{
Ele só pode durar se a última palavra não for jamais dita, e o último gesto jamais for completado. Portanto, a vitalidade interpessoal do ofício repousa por inteiro sobre os ombros de cada trabalhador, e todos são responsáveis por preservá-lo da imutabilidade.
}

É com humor que os encontramos, humor como substância que constitui o circular dos corpos em sua produção, em seus diversos funcionamentos. Humor que nos derruba das alturas de procurar a definição do que é ser motorista e nos arranca das profundidades de designar $\mathrm{o}$ que faz o motorista de fato, para correr com ele os acontecimentos da rua, habitando o corpo ônibus, o corpo cidade e qualquer corpo que produzamos em acoplamentos díspares, em aventuras. Para tanto, investimos um humor dos paradoxos (Deleuze, 1969/2007), que consiste em criar problemas em vez de procurar 
respostas para problemas naturalizados (Deleuze, 1966/1999), para combater o humor negro do corpo capitalista. “ $[\ldots]$ o humor negro se encarrega não de resolver as contradições, mas de fazer com que elas não existam, que jamais tenham existido. [...] $\mathrm{Na}$ verdade, nunca há contradições, aparentes ou reais, mas tão somente graus de humor." (Deleuze \& Guattari, 19721973/2010, p. 24.95). É o humor como buraco negro, que tende a tudo sugar e equivaler, que se procura combater pelo desenvolvimento do trabalho coletivo em singularizações. Se há contradições, o que já aponta para o buraco negro de anulação das forças entre si, trata-se de certas formas que os paradoxos de tensionamento entre as forças na atividade assumem, num grau menos elevado. A atividade, entretanto, sempre convoca a humorísticas como variações de intensidade do trabalho na experiência das situações produtivas.

Tomar a atividade do motorista de ônibus do transporte coletivo urbano como um tema de estudo é entrar numa paisagem de trabalho já em construção, cuja história não pode ser deixada de lado. Por esta perspectiva de abordagem do trabalho (Clot, 1999/2006), procuramos inventar saídas ao binarismo entre sujeito e objeto, entre trabalho e trabalhador, entre indivíduo e coletivo, entre pesquisador e pesquisado. Nessa paisagem problemática o que interessa são os acontecimentos. "O acontecimento não é o objeto como designado, mas o objeto como expresso ou exprimível, jamais presente, mas sempre já passado e ainda a vir" (Deleuze, 1969/2007, p. 139). "E a imagem que ele extrai de si mesmo não é uma imagem mentirosa, pois não lhe cabe responder ou não a uma realidade preexistente." (Deleuze, 1993/1997, p. 134). É nesse sentido que procuramos subverter a vontade de verdade estabelecida, a ser descoberta, pela vontade de verdade a ser inventada, em construção.

Deslocamos em nosso problema a centralidade do sujeito para focar a atividade produtiva, atividade que constitui e desconstitui as matérias de seu mundo de trabalho e vida. Isso não significa que desconsideramos a dimensão da subjetividade no trabalho, mas entendemola como fundamentalmente fabricada, como produzida em meio às máquinas de territórios de existência, em meios às atividades desenvolvidas no coletivo laboral. A subjetividade - os modos de vida - é a matéria-prima de toda produção (Guattari \& Rolnik, 1986/2008). Interessam-nos, primordialmente, essas máquinas como meios para a produção dos sujeitos e mundos do trabalho, esse plano coletivo multiplicizante e singularizante em que o motorista pode existir. 


\section{Perguntas sem resposta}

Que matérias e forças compõem o corpo motorista de ônibus? Para lidar com tal questão, consideramos que esse motorista de ônibus já é expressão de uma força em matérias que se compõem por relação: o motorista, o ônibus, a rua, o passageiro, o patrão, o botão, o volante, o freio, a moeda, a câmera de vídeo, etc. (Zamboni \& Barros, 2012b). Força de transportar coletivos pela cidade. Portanto, a força é sempre plural, está sempre em relação com outras forças (Deleuze, 1962/1976). Ao nos perguntarmos como se produz a atividade do motorista de ônibus, nos deparamos com um ser em constituição e luta no tempo, produzindo histórias que nunca se reduzem a uma única linha; ainda que (h)aja a dominância de uma história sobre outras, por vezes. Que sentidos se produzem na atividade desse motorista? Podemos com Nietzsche e Deleuze arriscar uma hipótese como princípio vertiginoso da nossa entrada nos mundos dos motoristas coletivos urbanos: "Uma coisa tem tantos sentidos quanto forem as forças capazes de se apoderar dela." (Deleuze, 1962/1976, p. 4).

Portanto, encontrar o sentido da atividade do motorista de ônibus é conhecer as forças que desse ser se apropriam, ou exploram, ou exprimem-se nele. A história da atividade do motorista é tecida nessa complexidade de sentidos, de lutas de forças, presente em cada gesto e ausência de gesto, em cada modulação gestual que o trabalhador põe em jogo para realizar a tarefa que ele se engaja pelas prescrições da organização do trabalho. Desse modo, encontramos na atividade do motorista de ônibus uma pluralidade de sentidos em função da pluralidade de forças em lutas na sua existência pelos mundos que habita. É essa pluralidade de forças e lutas que nos interessa na atividade do motorista.

Quando nos dispomos a conversar (Deleuze \& Parnet, 1977/1998) com os motoristas de ônibus do transporte coletivo urbano na Grande Vitória - ES, tomamos como dispositivo - ou seja, colocamos à disposição - os instrumentos teóricos e técnicos da clínica da atividade (Clot, 1999/2006, 2008/2010) e da esquizoanálise (Deleuze \& Guattari, 1972-1973/2010), de maneira a afirmar a primazia do trajeto analítico sobre quaisquer projetos que ali se firmassem. "O desafio é o de realizar uma reversão do sentido tradicional de método - não mais um caminhar para alcançar metas pré-fixadas (metá-hódos) [itálico dos autores], mas o primado do caminhar que traça, no percurso, suas metas." (Passos \& Barros, 2009).

Seguindo por este princípio vertiginoso, dispúnhamo-nos a desmontar os aparelhos de análise importados ou 
desenvolvidos em grandes fábricas acadêmicas transnacionais para compor e desenvolver as máquinas analíticas que os próprios motoristas arranjavam no cotidiano de trabalho. Procurávamos, assim, privilegiar a experiência concreta da atividade produtiva, em vez de partir das prescrições e ferramentas tal como estabelecidas, para desenvolver análises do trabalho (Zamboni \& Barros, 2012a). O que encontrávamos, então, junto com os motoristas, como dispositivo de análise do trabalho? Quando conversamos acerca do trabalho, os paradoxos emergem como situações problemáticas, vivíveis do trabalho - e não meramente o vivido -, que integravam casos diversos por uma linha abstrata incômoda forçando a pensar o trabalho.

- Motorista, esse ônibus vai reto?

- Motorista, por onde passa esse ônibus?

- Motorista, ...

(- $\mathrm{O}$ que eu faço com todas essas perguntas? Fico irritado, e já nem sei o porquê. Mas fico. Como eu saio disso?)

- Senhora, para onde deseja ir?

*

Ao (re)montar aqui este paradoxo do trabalho (re)formulado em conversação, indagamo-nos: qual é o problema que inventa viver o motorista nessa situação? Há uma força pela qual o motorista do transporte coletivo se agencia para existir e que lhe é essencial: o passageiro. Sem o passageiro, o motorista de ônibus desmancha a flexível linha que lhe traça um limite em relação a outros corpos linha que delimita um corpo a construir, funcionar e habitar, corpo situado. Dentre as múltiplas relações que o motorista estabelece, na história do seu gênero profissional (Clot, 1999/2006, 2008/2010), a relação com o passageiro é essencial. Sem ela, seu corpo muda radicalmente de sentido, o que lhe daria contornos distintos dos que se produzem em função da relação com o passageiro e que lhe possibilita relações com outros corpos. O sentido do seu trabalho está em jogo aí, na relação com o passageiro, que se inscreve como primordial à produção; embora a relação com os patrões e a hierarquia organizacional insista em sobrepor-se.

A condição intrínseca à produção do motorista de ônibus coletivo urbano é o passageiro (Zamboni \& Barros, 2012b). O motorista transporta passageiros e ele mesmo é um primeiro passageiro. $\mathrm{O}$ passageiro pode ser qualquer um e até qualquer coisa, se pensarmos algo diferente do humano individualizado. Podem ser malas e animais e rádios, dentre quaisquer outros que insistem em se fazer passageiros apesar das recusas oficiais. $\mathrm{O}$ passageiro não é exatamente o indivíduo, o cidadão, o homem. A figura do passageiro 
se compõe em meio a essas imagens, mas afirmando um personagem novo, sem o qual a produção de transporte é impensável. O passageiro configura a dimensão da alteridade no trabalho do motorista de ônibus. No plano de produção do seu trabalho, no meio de variações e imprevistos da atividade, o passageiro é tudo aquilo que pode trazer à cena incômodos e estranhamentos ao motorista, forçando desvios cruciais constitutivos da sua atividade.

Essa figura imanente à atividade do motorista é fundamental para pensar o seu trabalho - não a partir de imagens extrínsecas à sua produção como seria operando com o personagem cidadão, habitante da cidade, ou com o indivíduo, portador de direitos e deveres, ou com o homem, "como realidade espessa e primeira, como objeto difícil e sujeito soberano de todo conhecimento possível” (Foucault, 1966/2007, p. 427). O motorista compõe pela sua atividade o seu próprio contexto, suas paisagens, seu meio de trabalho no que esse contexto irá arranjálo. Aí emerge o personagem passageiro, com relativa coincidência com os personagens cidadão, indivíduo, homem; mas estes já são desfigurados na paisagem do transporte coletivo urbano produzida pelo motorista.

A partir dessas considerações sobre a dimensão passageira do trabalho do motorista, surpreende-nos, de imediato, a irritação como humor para viver a situação das perguntas sem resposta. Em conversas com vários motoristas, em diversos momentos e lugares, modos de irritação emergiam quando se evocava essa situação na conversa. Por que esse humor, e não outro qualquer? Como se constrói esta postura em relação à alteridade, ao estranhamento, que tais perguntas lhe apresentam? Ao trazer a situação à baila, o motorista perambula no conflito que se instala em seu corpo, que se constrói pelo coletivo, e sustenta a irritação como problema a viver. Mas, acaba por afirmar que a principal dificuldade do trabalho é o passageiro. De imediato, pode-se então estranhar que a relação essencial ao trabalho do motorista de ônibus coletivo urbano seja vivida como impedimento, obstáculo, entrave ao trabalho. Prender-se a esta sensação imediata, ou a qualquer outra, entretanto, nos impediria de abordar o jogo que aí se instala e no qual a irritação é um modo de funcionar inventado para prosseguir o trabalho, mas não único nem definitivo. Como se produz essa situação? Quais seus desenvolvimentos?

Pode-se também rir ou se assustar ou ter medo ou outros afetos quaisquer nessa situação. As questões colocadas pelo motorista - "o que eu faço com todas essas perguntas?", “fico irritado, e já nem sei o porquê", “como eu saio disso?" - podem 
ser vividas e arranjadas nos mais diversos modos, com os mais variados humores. Diante destas perguntas, podem-se levantar outras: De onde as pessoas inventam fazer esse tipo de perguntas? O que elas querem, afinal, com isso? O que se pode responder a elas? Essas questões que permeiam o problema construído no trabalho do motorista, e que aparecem no dispositivo clínico das conversas durante a pesquisa, podem funcionar como um desvio da primeira série de questões levantadas pelo motorista: questões que remetem a si no próprio trabalho.

Este si corre então o risco de se tornar si mesmo, tornar-se uma repetição do mesmo, uma atitude sem saída, na qual se fica preso num comportamento engessado. É também este o risco que habita o motorista em sua atividade: o humor em que funciona na situação, e que constitui a própria situação como um problema a viver, pode se fechar e não permitir vivê-la como uma fonte de criação de meios de agir para continuar o trabalho. O motorista diante das perguntas pode ficar paralisado, sem resposta possível. Ou ainda, reagir de modo a criar complicações no estabelecimento de relações com os passageiros, com os colegas e com a empresa. A questão a que se chega pode-se assim formular: o que fazer dos afetos no trabalho?

\section{Afetiva humorística}

Não se controlam completamente os afetos, as paixões entre os corpos, que são a fonte do humor que passa a correr em circuito pelo motorista em função do estranhamento proporcionado pela situação. $\mathrm{O}$ meio de trabalho e os instrumentos genéricos (Clot, 1999/2006) como modulações da ação e da expressão são maneiras de facilitar bons encontros, evitando os maus. As paixões, ao circularem, assumem um funcionamento que aqui remetemos fundamentalmente ao humor. Para Espinosa (1677/1983; Deleuze, 1981/2002) as paixões constituem os corpos, são efeitos dos encontros de corpos, uma constituição que se faz pela relação, na relação.

Para Vygotski (1998, p. 205, citado por Clot, 1999/2006, p. 32), “o sentir da emoção não tem tempo de assumir proporções inibidoras, o corpo é tonificado para agir”. A ação, contudo, não é imediata; é sempre desenvolvível, situável numa história, já que maquinada, mas também experimentada a cada vez, apresentando pontas de deriva, de mudança. A paixão entre os trabalhadores, construída por um meio comum, pode assim tornar-se em "emoções, corporalmente vivenciadas por cada um, [mas que] não deixam de ser socialmente construídas e compartilhadas - às vezes, 
inclusive, contagiosas." (Clot, 2008/2010, p. 9, nota de rodapé). Da emoção, extraemse os recursos do gesto (Clot, 1996/2006). Portanto, o funcionamento humorístico nunca se isola no sujeito: suas fontes (sources), assim como seus recursos (resources), estão sempre em jogo, em relação num meio de trabalho em construção coletiva.

Dessa maneira, o diálogo interior do motorista consigo próprio não é de modo algum isolável do diálogo exterior com o passageiro, o que nos leva a questionar radicalmente a função destas categorias dicotômicas de exterior e interior para as análises. Na situação que desenhamos em fragmento junto com o motorista, os parêntesis perpassam uma conversa na outra. É que o diálogo entre motorista e passageiro não se fecha no dualismo e na interpessoalidade binária, excludente do plano coletivo em que se compõem. Cabe ainda interrogar como o dispositivo clínico também diferencia essa situação, redesenhando a cena como processo de intervenção. Ao contrário do que se costuma estabelecer no campo da clínica, isolando a situação como conteúdo e o dispositivo clínico como forma, dicotomizando-os, trata-se de acompanhar seu coengendramento.

Há um jeito de perguntar e de responder que extrapola a cena, sem romper com ela. O diálogo se constitui por modos de pensar e agir que concorrem ao diálogo realizado, mas que não se esgotam nele: há o real do diálogo que, segundo Clot (1999/2006, 2008/2010), extrapola o realizado, evocando todo o campo de possíveis que o meio de trabalho dispõe pela atividade. As situações se constituem por essa concorrência que insiste, que não cessa, e que mantém o trabalho vivo, em tensionamento. Do contrário, acreditar-seia numa fórmula geral e final - sufocante sonho organizacional - para lidar com o motorista diagnosticado irritado. A irritação não é definitivamente um estado psicológico, mas antes uma via de subjetivação. As outras conversas possíveis, que a clínica da atividade visa ampliar, atravessam o diálogo realizado e compõem a multiplicidade da situação a viver.

A situação é a paisagem, o desenho, a cena composta a partir do estranhamento. Sendo assim, faz-se por relação, pela invenção de agenciamentos, por misturar paisagens para construir outras. Os motoristas forjam um plano comum de problemas pela situação de trabalho que compartilham: é esse plano que torna possível sustentar situações como problemas a viver e a pensar. Inventar paradoxos como provocações a invenção de maneiras de agir é crucial. Por que o motorista ao ser convidado a conversar acerca do seu trabalho traz essa situação? 
Por que a constrói de tal maneira, em vez de trazer outra situação qualquer e de outro modo? No plano comum da atividade coletiva do motorista, que podemos em clínica da atividade denominar gênero de trabalho, trata-se de “ [...] um verdadeiro trabalho do sentimento, uma modificação estética do afeto. [...] Ela não permite somente a expressão dos afetos. Ela não é seu exutório. [...] Tem-se a transformação de nossos afetos em um meio de viver outros afetos." (Clot, 2008/2010, p. 64). A transformação, portanto, é o que se passa já no próprio trabalho - e o que o dispositivo da clínica da atividade visa promover, auxiliar a desenvolver, inventando juntos outros modos e meios de viver o trabalho.

O que conta, afinal, são as forças em jogo na atividade, a multiplicidade de sentidos que a situação desenhada consegue sustentar. Essa situação é singular, repete-se pela insistência em diferir. Repete-se a cada vez que o motorista a revive, quando me fala dela, quando escrevo acerca, quando se recorda, quando age em função dela em outra situação. Mas cada repetição já difere, já se instaura num outro arranjo, já abre a paisagem às forças que a compõem para ensaiar outros desenhos. Enfim, ela difere em si própria, já que nunca se tem a mesma situação a não ser por impasse. Afinal, por que se construiria essa situação, essa cena, em nosso diálogo, se não fosse ela já um problema a viver, uma cutucada que força a pensar?

Procuramos escapar de uma abordagem que, ao prestar-se ao enaltecimento do trabalho do motorista, descolaria esse meio de produção social do plano de realidade, vinculando-o a ideais ascéticos. Seria o caso de tratarmos do trabalho do motorista como a dignidade de transportar pessoas, de ser alguém importante para o funcionamento da cidade, no orgulho de lidar com máquinas gigantescas e com trânsito extremamente complicado. Mas, na medida mesmo em que se vai permeando a honra e o orgulho do motorista com as situações paradoxais que os engendram nos processos de trabalho, esses valores se fragmentam em uma multiplicidade axiomática, em redes valorativas que colocam em jogo diversas avaliações e escolhas em conflito e produção pela atividade. Por esse meio, pode-se elogiar o trabalho do motorista de ônibus coletivo urbano sem exaltá-lo com ideais que colam em nosso pensamento e em nossas práticas.

Em tempos em que há um investimento maciço em relação aos modos de atendimento do cliente consumidor, comprador de serviço -, em que o motorista deve apresentar habilidades sociais pré-estabelecidas e ideais fixas para lidar com os passageiros e 
colegas de trabalho, há um sufocamento do desenvolvimento humorístico da atividade. Trata-se de tomar essa problemática desviando-lhe dos impasses de um afeto sobrecodificado, que a atrapalham o desenvolvimento por conta das prescrições transcendentes, impostas hierarquicamente. Sufocados as emoções e os sentimentos cultivados socialmente para serem usados como instrumentos, legado de um coletivo de trabalhadores, a atividade vital se encontra bloqueada, e o trabalhador tem aí um desafio para prosseguir o percurso do trabalho. Recusando as experiências e a humorística dos motoristas, a organização do trabalho se deteriora em regras supostamente universais de tratamento do cliente.

O que se passa, então, no paradoxo? Que paisagem problemática se desenha nele, por ele, com ele? Que sentidos esse paradoxo nos convoca a construir pelo (des)manchamento de representações sobre o trabalho do motorista? Pode parecer-nos à primeira vista, e o mesmo se dá com a organização do trabalho do transporte coletivo urbano público e privado, que o essencial do trabalho do motorista se estabelece pela relação com a máquina metálica movida à combustão sobre rodas móveis, o ônibus. O processo de formação do motorista é basicamente voltado para a função de dirigir esta máquina - numa concepção de sistema homem-máquina (Montmollin, 1967/1971) um tanto fechada sobre si mesma. Questões sociais e políticas se apresentam bastante reduzidas nas formações das autoescolas a anexos direção defensiva, ecologia - um tanto desligados do que seriam os temas principais - legislação de trânsito, mecânica de automóveis. Por essa perspectiva, visa-se um trabalhador mecanizado, cujo trabalho corresponderia a leis a obedecer estritamente. As questões situadas que se desenvolvem durante o processo coletivo de trabalho não encontram meios de formação na organização oficial do trabalho, embora fluam no cotidiano de encontros entre motoristas.

Essa formação mecanizada - mas, vale lembrar, nunca completamente, pois caberia colocar em análise os processos de formação pela atividade docente nas autoescolas, que sempre de algum modo podem escapar a isso - corresponde ao nosso olhar para o motorista cuja relação essencial se daria com a máquina metálica, se não tão só, primordialmente. Mas as nossas conversações clínicas com os motoristas nos encaminham por outra perspectiva, mudam radicalmente o ponto de vista hegemônico sobre seu trabalho e nos convidam a abordá-lo, a tomá-lo pelas bordas, pelos limites problemáticos, em vez de olhar sobre, desde um olhar das 
alturas para baixo. Estar junto é a condição para habitar essa paisagem, é uma construção cujos meios se inventa em relação.

Nessas conversações, o que se coloca são problemas coletivos, que tensionam a dicotomia entre individual e social: problemas com os passageiros, problemas com os outros agentes do transporte coletivo urbano. Tais problemas perpassam as relações com a máquina, como nos indica Guattari (1993/2003). Desse modo, as questões que os motoristas formulam também são imediatamente atravessadas por problemas técnicos $\mathrm{e}$ materiais, do funcionamento do ônibus, do trânsito, das câmeras de vigilância, de tal modo que se torna impossível distinguir completamente elementos técnicos e sociais, materiais e afetivos. Quando falamos em ônibus, vejam só, mal conseguimos distinguir um automóvel puramente técnico e um espaço puramente social, porque na atividade do motorista de ônibus, pelos processos analíticos que acompanhamos, não há distinção definida, mas coengendramento. $\mathrm{O}$ ônibus é imediatamente técnico, social, político, subjetivo, econômico, desejante, cognitivo. Cruza-se, então, a atividade de direção do veículo no trânsito de automóveis e a atividade de relação com o passageiro. A situação das perguntas sem resposta é um paradoxo do trabalho do motorista que se forma no cruzamento entre diversos eixos problemáticos do trabalho. Um destes eixos são as paradas nos pontos de passageiros, devido às dificuldades de retornar ao fluxo do trânsito. Trata-se de um corte no fluxo da atividade de atenção ao trabalho de dirigir do motorista pelo fluxo de perguntas sem resposta, por um lado; e, trata-se de um corte no fluxo do trânsito de automóveis pelo fluxo de passageiros que entra e sai pelos ônibus, de outro lado. O motorista irá afirmar nesse entrecruzamento de pessoas e automóveis com direções e perguntas, junto com vários outros, a problemática da atividade do motorista de ônibus.

\section{Uma conversa com motorista}

Motorista (M) - Muitos hoje já estão pedindo pra sair, que não está aguentando. Eu até agora não tenho o que reclamar, assim... fora o trânsito, não tenho o que reclamar. Tanto que eu já...

Clínico (C) - E esses que saem? O que que eles falam de porque está saindo?

$\mathrm{M}$ - Estresse. Eu vi um levantamento que é uma das profissões mais estressantes que tem. Porque é muito estressante mesmo. É muito para-para, buzina e... é muito estressante.

C - Você falou também, semana passada, a coisa das pessoas, né? 
M - É. Pessoas... o comodismo, a educação que sai de casa. A pessoa acomoda, o comodismo: você tá parado aqui, a pessoa não anda dois metros, aí você tem que sair daqui, andar dois metros pra pegar ela de novo. Está no direito dela; mas, poxa, tem que haver o bom senso, né? Já está parado aqui, dois metros, vai parar de novo? Aí, as pessoas acham... O desgaste. Vai desgaste de embreagem, de freio. Há o desgaste. Não é eu que vou pagar, não é ela...

Outros $(\mathrm{O})-\ldots$ me prepara mais...?

M - Rapidim?

O - Rapidão!

(silêncio e barulhos da rua)

C - E pra você, como é que é o desgaste? Com essas coisas aí, nessa situação.

M - Rapaz, eu, graças a deus, eu trabalho na... Mas eu trabalho até brincando. Porque não adianta você se estressar que, igual assim, um passageiro vem, perturba ali: ele vai descer no outro ponto, você vai ter que ficar ali. Você vai ficar brigando? Arrumar confusão? Não! Ele vai descer no outro, né? E você vai embora! Só que tem uns que é um... tem uns que é um...

O - Pela-saco!

$\mathrm{M}-\ldots$ É de doer mesmo!

$\mathrm{C}$ - Como é que é?

$\mathrm{M}-\mathrm{E}$, é igual estou te falando do estresse. É muita coisa que incomoda. É!
Aqueles meninos que entram com o radinho alto, sentam atrás de você, fica... alto. É, pessoas... Igual hoje. Tem uma senhora que, às vezes, ninguém gosta de embarcar ela.

$$
\begin{aligned}
& \text { C - Por quê? } \\
& \text { M - Rapaz, ela não tem... não é }
\end{aligned}
$$

muito certa da ideia não. Ela fica gritando a viagem toda. Vê um na rua, fica gritando “ê, cuidado com não sei o que, ê". Aí, aí é meio tenso você...

(silêncios e barulhos da rua)

C - Então, camarada, você estava falando do passageiro...

$$
\begin{aligned}
& \text { M-É. } \\
& \text { C-Tem uma senhora que... } \\
& \text { M - Que ela é muito escandalosa. }
\end{aligned}
$$

Grita muito. A gente pede pra poder, né, falar mais baixo. Incomoda, não só a gente, como outros passageiros.

\section{$\mathrm{C}$ - Você mesmo pede?}

M - Peço. Aí, eu sou o condutor, ela grita mais ainda. Fala que não vai parar. E você vai fazer o que? Botar pra fora é o que... não vai... Você tem que aguentar. Tem que aguentar porque é complicado, né. É... pessoas mal-educadas, acha ruim com tudo. Se você parar um pouco fora do ponto, eles acham ruim. Se você parar antes, acham ruim. Se você parar depois, acham ruim. É muito complicado. Mas, a gente precisa trabalhar, né?! 
M - Não sou... creio que não seja um mau funcionário, entendeu? A gente ta ae.

C - Você falou que vai entrar de férias, né?

M - Vou, graças a deus. Terçafeira, eu estou de férias.

C - Você pega sempre as suas férias? $\mathrm{Ou}$, você, às vezes, vende as férias?

$M$ - Não. Eu pego as férias. Eu já fico o ano todo esperando as férias. Eu já... eu saio agora em..., volto em..., já estou querendo outras férias já.

$\mathrm{O}$ - Você está de férias, ...?

M - Não. Terça-feira.

O - Né?! Então, agora a gente vai... o dia inteiro.

M - Num [a]guento não. A gente acorda muito cedo.

C - E se eu fosse te substituir, o que que você falava preu [para eu] fazer? Como que eu tenho que fazer seu trabalho?

$$
\begin{aligned}
& \text { M-Paciência! } \\
& \text { C-Paciência? } \\
& \text { M-É! } \\
& \text { C-Por quê? } \\
& \text { M-Tranquilidade! Porque tem que }
\end{aligned}
$$
ter paciência, né?! Às vezes, você para duas, três vezes, no mesmo ponto. É, é... Acho que todo motorista... - Boa noite! É.... Acho que todo motorista tem alguns pontos que não gostam de parar, tem alguns pontos que não gosta de parar... - ... Boa noite! Sim?!...
M - Aí, falando, aí sempre tem uns pontos que não gostam de parar. Que esses pontos mais chatos não é nem questão da parada, é mais questão de ter que sair dele depois. O pessoal não deixa sair, não deixa você voltar, retornar pra pista. Aí, você já aí... quando você passa direto aquele ponto, você fica até feliz.

$$
\begin{aligned}
& \text { C - Você fala do trânsito, no caso? } \\
& \text { M-É. } \\
& \text { C - .. } \\
& \text { M - Oi?! } \\
& \text { C - Esse é o ponto ruim? O ponto }
\end{aligned}
$$
em que o trânsito atrapalha a parar e... de volta?

M - É assim... ponto que você dá uma parada, aí, depois, pra você retornar pra pista, porque o pessoal não deixa você voltar...

C - Mas, como é que você faz?

$\mathrm{M}$ - Você tem que esperar e..., ou então, ir botando o bico do carro devagar e devagar e devagar... até...

C - Até deixar você passar, né?

(silêncio)

(conversas várias)

M - É. Aí, tem uns... são três pontos que, na linha que eu faço, que eu num... é, que é na, no bairro..., que é um no meio do morro...

C - No meio do morro, você fala na subida?

M - É. Na ladeira. E... dois na..., ali em... Esse da... não é questão de voltar pra 
pista, é questão de você parar no meio do morro.

C - Mas, como é que você faz? Você entra...?

M - Não! É no meio da pista, no meio da pista.

C - Não tem problema?

M - Não. Por que é a parada mesmo. -..., boa noite!

\section{Variações dialógicas}

A partir desse trecho que montamos com uma conversação gravada com motorista de ônibus - o mesmo (?!) que compartilhou conosco primeiramente $\mathrm{o}$ paradoxo das perguntas sem resposta, que mais tarde circulou em diversas outras conversas com outros motoristas -, podemos desenvolver a discussão acerca atividade do motorista de ônibus do transporte coletivo urbano como sendo uma atividade imediatamente material e social, sem distinções possíveis a não ser no plano das representações. Pela análise da atividade, esta distinção se mostra infrutífera e atrapalhando a análise por preestabelecer o critério. Vejamos, então, como esse processo de trabalho se desenvolve a partir da análise paradoxal da atividade.

Pelo recorte que fazemos, é importante considerar que essa conversa se faz durante a atividade de trabalho de vendedor, que concorre com sua atividade de motorista trabalhando em dois empregos. O diálogo é permeado por barulhos do trabalho, de outras conversações que cruzam incessantemente o diálogo, seja por colegas de trabalho de vendas, seja por clientes. Há, inclusive, intervenções desses outros sujeitos no diálogo, das quais conseguimos registrar algumas aqui.

Pontuemos questões importantes para nós em relação ao trecho de conversa gravado. Inicialmente, a posição discursiva do motorista constrói um lugar de constatação de acontecimentos por alguém que trabalha no meio do transporte coletivo urbano. A seguir, ele se coloca em relação a isso que se constata, interpelado por perguntas ou não. Afirma assim que não há problema além do trânsito. Mas que trânsito? Inquietamo-nos. Evoca-se também o conceito de estresse, ainda bastante comum ao se discutir as relações entre saúde e trabalho, e complicador para a análise dos processos de trabalho já que remete a uma concepção de saúde que

\footnotetext{
tende ordinariamente a reduzir os problemas a um nível estritamente individual... [e] contenta-se com efeito a sugerir uma saudável gestão do estresse... [de maneira que] As condições de trabalho são aí largamente ignoradas por conta da luta contra o tabagismo, a promoção do
} 
exercício físico e diversas técnicas de relaxamento. (Chanlat, 1990, p. 123, tradução nossa).

Entretanto, pela clínica, essa abordagem hegemônica da saúde no trabalho já se desvia pela conversação, retomando o tema que se desenvolvia na conversa da semana anterior, pela qual se produziu o paradoxo das perguntas sem resposta, focando numa problemática primordial ao trabalho do motorista: a relação com o passageiro.

Cabe ressaltar que esta direção inicial do diálogo é composta pelo gravador de áudio, que não se fazia presente na conversa anterior com $o$ motorista. $\mathrm{O}$ uso do gravador modifica o tom da conversa. O aparelho audiográfico, assim como a atividade de trabalho de vendedor, irá compor nosso meio dialógico clínico. A princípio, o diálogo é hesitante apesar da confiança já estabelecida. Em contraste, o final do trecho dialógico compõe-se de debates evocando elementos passíveis de identificação - que apagamos aqui -, indicando outro rumo para a conversa. Contudo, não se trata do gravador apenas como máquina técnica, mas do seu funcionamento num regime de processos de trabalho em transporte coletivo urbano.

Insiste deste modo, como sobredestinatário dialógico, a organização do trabalho. Esta se presentifica pelo gravador, ou seja, pelo registro e arquivamento da atividade relacionada ao trabalho, que remete à vigilância, controle e punição individuais marcantes nas empresas privadas que contratam e administram o trabalho dos motoristas. Ao indicar que os prejuízos são mecânicos e relativos ao ônibus, o endereçamento do diálogo marca a pungência da organização empresarial no trabalho. Ao questionarmos sobre seu próprio desgaste, o motorista traz à cena a dimensão da brincadeira e do humor no trabalho objetificados em instrumentos para agir; assim também se expõe o saber formulado coletivamente, e já indicado pelos motoristas que conversam com Pinto (2001), acerca do passageiro como aquele que passa diante do motorista que permanece e que, por isso, precisa e pode suportar. Estranhamos ainda isso, uma vez que no paradoxo a irritação do motorista comparece sem tanta cerimônia. Mas o motorista não deixa de evocar os casos mais difíceis, "de doer mesmo!".

E, ao apresentar os personagens do seu drama laboral, o motorista formula problemas acerca do trabalho. Diante do passageiro incômodo e barulhento, seja pelo rádio alto ou pelos gritos loucos, decide-se não proceder à retirada do passageiro. Mas, na tentativa de incitar o passageiro a atender ao pedido do 
responsável pelo ônibus, o motorista sente que o não atendimento marca uma desconsideração da sua incumbência. Então, a fórmula do trabalho que daí se extrairá é o "tem que aguentar porque é complicado", que logo remeterá aos sentimentos de paciência e tranquilidade, tornados necessários ao prosseguimento do trabalho.

O motorista, então, evoca a situação das várias paradas no mesmo ponto em função da atitude acomodada dos passageiros. Elegem-se os pontos complicados de paradas para passageiros na ladeira e numa via bastante movimentada, cujos nomes riscamos. Revezam-se, nessa interlocução, os elementos sociais e os elementos materiais em função do sobredestinatário do diálogo, ou seja, da polifonia discursiva do meio de trabalho. Aí se pode traçar nitidamente a posição do poder organizador; mas, também, promove-se o diálogo desde a experiência do gênero profissional, trazendo a situação dos colegas de maneira a remeter a questões genéricas daqueles que compartilham um horizonte profissional comum. Quando o motorista usa o termo "você" para indicar o que se faz, o que se sente, o que se deve fazer ou sentir, aponta para as normatizações genéricas assentadas pelo próprio coletivo de trabalho. Essas normatizações nunca correspondem exatamente à atividade, trata-se da sedimentação da experiência, do aprendizado para agir. $\mathrm{Na}$ experimentação cotidiana do trabalho, este solo da experiência sedimentado move-se em função dos percursos a realizar. Se as normatizações mostram-se endurecidas ou mesmo muito distantes do realizável, com pouca potência instrumental para $\mathrm{o}$ trabalho, trata-se do enfraquecimento do gênero profissional, do qual é preciso cuidar como instituição laboral.

A estilização do trabalho, entretanto, já se encontra entre "você" e “eu”, referentes usados no discurso acerca do trabalho pelo motorista. Não seria o caso de assinalarmos um discurso genérico quando usa "você", ou outros termos correspondentes, opondo-o a um discurso estilizado quando usa "eu". A análise discursiva, dessa maneira, ainda deixaria de acompanhar os entremeios dessa conversa. O estilo já está presente no próprio discurso genérico, não é uma atribuição individual (Clot, 1999/2006, 2008/2010). Se esse motorista com quem conversamos aponta que não se tira o passageiro do ônibus, veremos que essa não é uma normatização indicando um modo único de agir. Há diversas maneiras de lidar com isso que se acorda entre os motoristas. E, imediatamente, o motorista com quem dialogamos destaca isso pelos modos como lida com essa conflitiva do trabalho. 


\section{Transportes}

Partimos da ideia de que os motoristas não meramente executam 0 trabalho que os organizadores do transporte coletivo urbano pensam, como nos indica "A ergonomia em busca de seus princípios" (Daniellou, 1996/2004), por entendermos sua atividade como um plano de produção, uma máquina. Os motoristas de ônibus produzem transporte promovendo circulação de pessoas e pensam pela invenção de transportes, de modos de transportar. Como o filósofo que pensa por meio dos conceitos, o artista que pensa por meio das composições e os cientistas que pensam por meio de funções (Deleuze \& Guattari, 1991/1997), o motorista pensa por meio de transportes.

Desse modo, questionamo-nos: que transportes seriam os produzidos pelos motoristas de ônibus coletivo urbano? Não são os mesmos transportes que operam seus colegas rodoviários em outros meios de trabalho, mas certamente estão constituídos por diversos vetores comuns, já que os trabalhadores frequentemente transitam entre diferentes tipos de trabalho como motoristas - de cargas ou individual, por exemplo. $O$ transporte coletivo na cidade é possível por um corpo genérico composto pelas estilizações que os motoristas de ônibus coletivo urbano constroem como invenção do trabalho. Isto não implica uma dissociação do meio rodoviário, mas a emergência de questões próprias aos motoristas de ônibus coletivo urbano por esse cruzamento com outros gêneros de atividade, rodoviários ou não.

No caso das perguntas incômodas dos passageiros, o que constitui problema para o motorista é como transportá-las. Trata-se de uma série de perguntas que o motorista forja a partir de distintos momentos, traçando entre elas um contínuo para expressar uma situação precisa, mas que não se reduz a um momento ou outro. A situação e sua problemática se instalam nesses entremomentos. Assim como os afetos produzidos por essa situação e os modos como o motorista os apreende em emoções e sentimentos produzem outras séries problemáticas como (cor)respondentes da série de perguntas. Mas não se permanece na ordem dos efeitos: é, antes, o caso de tomá-los pela atividade e deles fazer alguma coisa. No trabalho, instala-se para si a situação no que se inventam saídas: a construção de uma situação começa pela ação que experimenta. E, quanto mais se produz um plano coletivo de invenção destas saídas, plano de sustentação problemática - que não significa encontrar vias similares, iguais, perfeitas ou finais de vias comuns que se abram a modos vários de proceder, mais o trabalho se 
fortalece em função da autonomia coletiva, oposta a individualização culpabilizante.

Mas, o que há de problemático na série de perguntas? Assim como a louca que incomoda o motorista com suas gritarias e as paradas difíceis durante o trajeto de ônibus, essas perguntas desestabilizam a organização do trabalho no motorista. Trata-se de um problema bastante complexo, já que a circulação automobilística na cidade está bastante organizada em termos de regras e leis. Mas a organização do trânsito não é meramente material, relativa às ruas e aos automóveis apenas. Tal organização implica uma apropriação subjetiva, que não é nunca meramente um reflexo de espelho da objetividade mais ou menos embaçado. A série de perguntas desloca a lógica predominante no trabalho do motorista: a racionalidade do trânsito organizado pela cronológica do tempo útil e demarcado a não perder o quanto possível é questionada pela situação vívida no trabalhador.

Diante da série problemática aberta pela situação paradoxal, a intervenção clínica pode (re)construí-la junto com os motoristas como um meio de interferências visando ampliar o poder de agir do trabalhador. Isto implica ampliar o poder de ser afetado pela situação, como nos diz Clot (2008/2010). Esta ampliação do poder de ser afetado é crucial para que o trabalhador e o clínico se coloquem mais uma vez na situação; de modo a não rejeitá-la como dificuldade tão somente contornável ou suportável, considerada imutável. É preciso aí tomar a situação como construção do plano de forças que se afetam e que cabe habitar para transformar. Deste modo, nossa intervenção clínica encontra como acento a ética em tempos de tecnologização das relações humanas em função de um controle das emoções bastante prescritas. Com isso, não é o caso de menosprezar as técnicas de intervenção desenvolvidas pela clínica da atividade, como é a autoconfrontação cruzada e a instrução ao sósia (Clot, 1999/2006, 2008/2010), mas de lançá-las continuamente ao seu plano ético de constituição, às situações concretas de trabalho - questionando seus efeitos, sempre diversos.

A surpresa com a irritação que o motorista desenvolve diante das perguntas sem resposta é acompanhada por riso, que toma de assalto o clínico durante o diálogo. Procurando melhor desenhar com o motorista a paisagem da situação, explorando suas nuances, os risos do clínico confrontam e são confrontados pela irritação do motorista. "A expressão do humor pelo analista implica, portanto, rir com o analisando, nunca do analisando, já que o mais próprio da atitude humorística é a capacidade de rir de si mesmo." (Kupermann, 2003, p. 254, grifos do 
autor). Trata-se de uma interferência mútua em que está em jogo o desenvolvimento de perspectivas relativas ao trabalho, aos modos de proceder pela atividade. O clínico, desmontando junto com o motorista a maquinaria bastante complexa da autoconfrontação cruzada e da instrução ao sósia, usa os pedaços que lhe convém na análise psicológica do trabalho, experimentando-os em função da conversa como ela se desenvolve.

A situação ainda se repete um bom número de vezes pela clínica afora. Em várias conversações, o clínico junto com diversos motoristas toma a situação como objeto de conversa a compartilhar na rede aberta e indireta de encontros. A cada vez, uma tonalidade humorística variante. Há o motorista que já ri de imediato quando lhe acontecem as perguntas sem resposta. Há ainda outro que fica estupefato. Os humores dialogam pela confrontação humorística; pois, pelo diálogo, traz-se à cena outro modo de viver a situação, outras configurações de força pela paisagem de produção do transporte. Convocam-se conversações indiretas em que o diálogo se traça entre humores, antes que entre indivíduos ou sujeitos. E a intervenção se processa, sobretudo, nesse confronto entre humores; já não se sabendo pertencentes a quem, nem se se trata de uma autoconfrontação simples ou cruzada. Talvez, seria o caso de definir um procedimento de transconfrontação. Confrontações que se promovem por suportes diversos como planos afetivos para o desenvolvimento do poder de agir.

\section{Referências}

Chanlat, J-F. (1990). Théories du stress et psychopathologie du travail. Prevenir, 20(1), 117-125.

Clot, Y. (2006). A função psicológica do trabalho. Petrópolis, RJ: Vozes. (Original publicado em 1999)

Clot, Y. (2010). Trabalho e poder de agir. Belo Horizonte: Fabrefactum. (Original publicado em 2008)

Clot, Y. (2011). Clínica do trabalho e clínica da atividade. In P. F. Bendassoli \& L. A. P. Soboll (Orgs.), Clínicas do trabalho: novas perspectivas para compreensão do trabalho na atualidade (pp. 71-83). São Paulo: Atlas. (Original publicado em 2006)

Daniellou, F. (Org.). (2004). A ergonomia em busca de seus princípios: debates epistemológicos. São Paulo: Edgard Blücher. (Original publicado em 1996)

Deleuze, G. (1976). Nietzsche $e \quad a$ Filosofia. Rio de Janeiro: Ed. Rio. (Original publicado em 1962) 
Deleuze, G. (1999). Bergsonismo. São Paulo: Ed. 34. (Original publicado em 1966)

Deleuze, G. (2007). Lógica do sentido. São Paulo: Perspectiva. (Original publicado em 1969)

Deleuze, G. (2002). Espinosa: filosofia prática. São Paulo: Escuta. (Original publicado em 1981)

Deleuze, G. (1997). Crítica e clínica. São Paulo: Ed. 34. (Original publicado em 1993)

Deleuze, G., \& Guattari, F. (2010). $O$ antiédipo: capitalismo e esquizofrenia 1. São Paulo: Ed. 34. (Original publicado em 1972-1973)

Deleuze, G., \& Guattari, F. (1997). O que é a filosofia?. São Paulo: Ed. 34. (Original publicado em 1991)

Deleuze, G., \& Parnet, C. (1998). Diálogos. São Paulo: Escuta. (Original publicado em 1977)

Espinosa, B. (1983). Ética: demonstrada à maneira dos geômetras. In B. Espinosa, Pensamentos metafísicos; tratado de correção do intelecto; ética; tratado político; correspondência (pp. 69-300). São Paulo: Abril Cultural. (Original publicado em 1677)

Falzon, P. (Org.). (2007). Ergonomia. São Paulo: Edgard Blücher. (Original publicado em 2004)
Foucault, M. (2007). As palavras e as coisas: uma arqueologia das ciências humanas. São Paulo: Martins Fontes. (Original publicado em 1966)

Guattari, F. (2003). A paixão das máquinas. In $\mathrm{O}$ reencantamento do concreto (pp. 39-52). São Paulo: Hucitec. (Original publicado em 1993)

Guattari, F., \& Rolnik, S. (2008). Micropolítica: cartografias do desejo. Petrópolis, RJ: Vozes. (Original publicado em 1986)

Kupermann, D. (2003). Ousar rir: humor, criação e psicanálise. Rio de Janeiro: Civilização Brasileira.

Montmollin, M. (1971). Introducción a la ergonomía: los sistemas hombresmáquinas. Madrid: Aguilar. (Original publicado em 1967)

Passos, E., \& Barros, R. B. (2009). A cartografia como método de pesquisa-intervenção. In E. Passos, V. Kastrup \& L. da Escóssia (Orgs.), Pistas do método da cartografia: Pesquisa-intervenção e produção de subjetividade (pp. 17-31). Porto Alegre: Sulina.

Pinto, F. M. (2001). Trabalho e saúde mental: um estudo com motoristas de ônibus de João Pessoa-PB. Dissertação de Mestrado, Programa de Pós-Graduação em Serviço 
Social, Universidade Federal da Paraíba, João Pessoa.

Zamboni, J., \& Barros, M. E. B. (2012a). Micropolítica da atividade. Barbarói, $\quad 36(1), \quad$ 113-137. Recuperado em 12 setembro, 2012, de

https://online.unisc.br/seer/index.ph p/barbaroi/article/viewFile/2442/21 64

Zamboni, J., \& Barros, M. E. B. (2012b). Paradoxo do motorista de ônibus como passageiro: subjetividade, atividade, videografia. ECOS Estudos Contemporâneos da Subjetividade, 2(2), 319-331. Recuperado em 1 abril, 2013, de http://www.uff.br/periodicoshuman as/index.php/ecos/article/view/760/ $\underline{724 \mathrm{~A}}$

Jésio Zamboni: Graduado em Psicologia (2008), Mestre em Psicologia Institucional (2011), Doutorando em Educação e Pesquisador do Núcleo de Estudos e Pesquisas em Subjetividade e Políticas (NEPESP) e do Grupo de Estudos em Sexualidades (GEPSs) pela Universidade Federal do Espírito Santo. Bolsista da Fundação de Amparo à Pesquisa do Espírito Santo (FAPES).

E-mail: jesio.zamboni@ufes.br
Maria Elizabeth Barros de Barros: Professora Titular do Departamento de Psicologia e dos Programas de PósGraduação em Psicologia Institucional (PPGPSI) e em Educação (PPGE) da Universidade Federal do Espírito Santo. Possui Graduação em Psicologia pela Universidade Federal do Rio de Janeiro (1975), Mestrado em Psicologia Escolar pela Universidade Gama Filho (1980), Doutorado em Educação Brasileira pela Universidade Federal do Rio de Janeiro (1995) e PósDoutorado em Saúde Coletiva pela ENSP/Fiocruz (2001). Pesquisadora do Núcleo de Estudos e Pesquisas em Subjetividade e Políticas.

E-mail: betebarros@uol.com.br 